\title{
Paenibacillus woosongensis sp. nov., a xylanolytic bacterium isolated from forest soil
}

\author{
Correspondence \\ Ki-Hong Yoon \\ ykh@lion.woosong.ac.kr
}

\author{
Jae-Chan Lee ${ }^{1}$ and Ki-Hong Yoon ${ }^{2}$ \\ ${ }^{1}$ Korea Research Institute of Bioscience and Biotechnology, 52 Oeun-dong, Yusong-gu, \\ Daejeon 305-333, Republic of Korea \\ ${ }^{2}$ School of Food Science and Biotechnology, Woosong University, 17-2, Jayang-dong, \\ Dong-gu Daejeon 300-718, Republic of Korea
}

Xylan is a heterogeneous and abundant polysaccharide in nature: it is composed of $(1,4)$-linked $\beta$-D-xylosyl residues and is the major component of hemicelluloses in monocotyledon cell walls (Timell, 1967). Xylanases ( $\beta$ $1,4-\mathrm{D}$-xylan xylanohydrolase and $\beta$-1,4-D-xylan xylohydrolase), produced by a wide range of micro-organisms, are a group of xylanolytic enzymes that hydrolyse xylan to xylan oligosaccharides and xylose, and are used in the pulp industry and in the production of biofuels (Viikari et al., 1994; Lamed et al., 1988). The genus Paenibacillus was originally proposed by Ash et al. (1993) [the name was validly published by Ash et al. (1994)] and its members are facultative anaerobes or strict aerobes that produce spores in swollen sporangia and have DNA G $+\mathrm{C}$ contents in the range $45-54 \mathrm{~mol} \%$. It contains some species that are able to degrade xylan (Zamost et al., 1991; Morales et al., 1995; Hespell, 1996; Nielsen \& Sorensen, 1997; Aÿ et al., 1998; Lee et al., 2000; Velázquez et al., 2004; Rivas et al., 2005).

During the screening of xylan-degrading bacteria, strain YB- $45^{\mathrm{T}}$ was isolated from forest soil at Daejeon in Korea. For the isolation, soil samples were diluted serially with $0.85 \%(\mathrm{NaCl}, \mathrm{w} / \mathrm{v})$ saline solution. Aliquots of each serial dilution were spread on Luria-Bertani agar (Difco) supplemented with $0.5 \%$ xylan (from oat spelt; Sigma)

The GenBank/EMBL/DDBJ accession number for the 16S rRNA gene sequence of strain $Y B-45^{\top}$ is $A Y 847463$. and incubated at $37{ }^{\circ} \mathrm{C}$ for $1-2$ days. A colony with a conspicuous halo was isolated and the isolate $\left(\mathrm{YB}-45^{\mathrm{T}}\right)$ was routinely grown aerobically on tryptic soy broth (TSB; Difco) for 1-2 days at $37{ }^{\circ} \mathrm{C}$ except where indicated otherwise. Cultures in liquid medium were incubated at $37^{\circ} \mathrm{C}$ in a rotary shaker at 150 r.p.m. Cell growth was monitored by measuring $\mathrm{OD}_{600}$. Cell biomass of strain $\mathrm{YB}-$ $45^{\mathrm{T}}$ was obtained from TSB cultures at $37^{\circ} \mathrm{C}$. Any requirement for and tolerance of $\mathrm{NaCl}(0-10 \%)$ were determined in tryptic soy agar (TSA; Difco). To test for growth on $0 \% \mathrm{NaCl}$, this compound was omitted from the TSB. Growth was tested in TSB at different temperatures (4$60{ }^{\circ} \mathrm{C}$ ) and $\mathrm{pH}$ values (5.0-10.0). Cell morphology was studied by using light microscopy and transmission electron microscopy. Motility was investigated in wet mounts under a light microscope (E600; Nikon) at 12 and $36 \mathrm{~h}$. Flagellation was investigated with transmission electron microscopy, using cells from the exponential growth phase. The cells were mounted on Formvar-coated copper grids and negatively stained with $1 \%$ potassium phosphotungstate ( $\mathrm{pH} 7.0$ ); the grids were examined in a Phillips 201 transmission electron microscope operated at $80 \mathrm{kV}$. The presence of endospores was investigated by using the Schaeffer-Fulton staining method (Smibert \& Krieg, 1981). Gram staining was determined by using a bioMérieux Gram Stain kit according to the manufacturer's instructions. Catalase activity was determined from bubble 
production in a $3 \%(\mathrm{v} / \mathrm{v})$ aqueous hydrogen peroxide solution. Oxidase activity was tested by using oxidation of $1 \%(\mathrm{w} / \mathrm{v})$ tetramethyl-p-phenylenediamine with a Bactident Oxidase strip (Merck). The hydrolysis of compounds was checked on TSA according to the methods described by Cowan \& Steel (1965), Lanyi (1987) and Smibert \& Krieg (1994). Nitrate reduction and the hydrolysis of tyrosine, Tweens 20 and 80, aesculin, casein, starch and gelatin were investigated according to the method of Lanyi (1987). Carbon-source utilization tests, acid-production tests and additional physiological tests were performed by using API $50 \mathrm{CH}$, API 50CHB and API 20NE galleries according to the instructions of the manufacturer (bioMérieux). Growth under anaerobic conditions was determined in an anaerobic chamber $\left(\mathrm{H}_{2}: \mathrm{CO}_{2}: \mathrm{N}_{2}, 5: 10: 85\right.$; Mart Microbiology) after 2 days incubation at $37{ }^{\circ} \mathrm{C}$ on TSA.
Strain $\mathrm{YB}-45^{\mathrm{T}}$ was isolated on Luria-Bertani plates and showed high levels of xylanolytic activity. Within $48 \mathrm{~h}$ on TSA at $37{ }^{\circ} \mathrm{C}$, the colonies produced were visible $(1-2 \mathrm{~mm}$ diameter), light beige to greyish, low convex, circular with slightly irregular edges, translucent and glossy. The strain was facultatively anaerobic and the cells were motile rods (0.5-0.7 $\mu \mathrm{m}$ wide and $2.5-5.0 \mu \mathrm{m}$ long). Growth was observed at temperatures ranging from 28 to $47^{\circ} \mathrm{C}$; optimum growth occurred at $37^{\circ} \mathrm{C}$ and $\mathrm{pH}$ 7.5. The cells were Gram-variable, catalase-positive and oxidase-negative, did not reduce nitrate to nitrite and produced single, ellipsoidal, terminal endospores in swollen sporangia. Strain $\mathrm{YB}-45^{\mathrm{T}}$ differed from phylogenetically related species in that it was capable of growth at $47{ }^{\circ} \mathrm{C}$. Other physiological and biochemical characteristics are summarized in Table 1 and the species description.

Table 1. Phenotypic characteristics that differentiate strain YB- $45^{\top}$ from related members of the genus Paenibacillus

Taxa: 1, strain YB-45 ${ }^{\mathrm{T}}$; 2, P. jamilae; 3, P. polymyxa; 4, P. azotofixans; 5, P. peoriae; 6, P. kribbensis; 7, P. terrae; 8, P. brasilensis. All species formed swollen sporangia and were positive for anaerobic growth, catalase, acid production from arbutin, D-cellobiose, D-fructose, D-glucose, glycogen, maltose, D-mannose, D-mannitol and salicin and growth at $\mathrm{pH}$ 5.6. All species were negative for oxidase and growth in the presence of $5 \% \mathrm{NaCl}$. Data for P. jamilae, P. polymyxa, P. azotofixans, P. peoriae, P. kribbensis and P. terrae are from Yoon et al. (2003) and data for P. brasilensis are from von der Weid et al. (2002). NT, Not tested; +, positive; -, negative; W, weak; v, variable.

\begin{tabular}{|c|c|c|c|c|c|c|c|c|}
\hline Characteristic & 1 & 2 & 3 & 4 & 5 & 6 & 7 & 8 \\
\hline Nitrate reduction & - & + & + & - & + & + & + & + \\
\hline Casein & + & + & + & - & + & + & + & + \\
\hline Gelatin & - & + & + & - & + & + & + & $\mathrm{V}$ \\
\hline Starch & + & + & + & - & + & + & + & + \\
\hline \multicolumn{9}{|l|}{ Utilization of: } \\
\hline L-Arabinose & + & NT & NT & NT & NT & + & - & - \\
\hline D-Fructose & + & NT & NT & NT & NT & + & - & NT \\
\hline D-Ribose & + & NT & NT & NT & NT & + & - & NT \\
\hline D-Xylose & + & NT & NT & NT & NT & + & - & - \\
\hline Citrate & - & - & - & - & + & $\mathrm{w}$ & $\mathrm{w}$ & + \\
\hline Glycerol & - & + & + & - & $\mathrm{V}$ & $\mathrm{w}$ & + & - \\
\hline D-Ribose & + & + & + & - & + & + & + & + \\
\hline Trehalose & + & + & + & + & - & + & + & $\mathrm{V}$ \\
\hline Turanose & $\mathrm{w}$ & + & + & + & $\mathrm{V}$ & - & + & $\mathrm{V}$ \\
\hline D-Xylose & + & + & + & - & + & + & + & - \\
\hline Methyl $\beta$-D-xyloside & + & - & + & - & + & + & $\mathrm{w}$ & - \\
\hline Methyl $\alpha$-D-mannoside & + & NT & - & - & + & $\mathrm{w}$ & + & - \\
\hline 2-Ketogluconate & - & NT & - & + & - & - & - & - \\
\hline 5-Ketogluconate & - & NT & - & + & - & - & $\mathrm{w}$ & - \\
\hline Growth with $2 \% \mathrm{NaCl}$ & + & + & NT & $\mathrm{V}$ & NT & + & + & + \\
\hline Growth at $47{ }^{\circ} \mathrm{C}$ & + & - & - & - & - & - & - & - \\
\hline
\end{tabular}

*Abbreviations: E, ellipsoidal; O, oval. 
Fatty acid methyl esters were analysed by GC/MS according to the instructions of the Microbial Identification system (MIDI; Microbial ID). Isoprenoid quinones were analysed as described by Komagata \& Suzuki (1987), using HPLC apparatus fitted with a reversed-phase column (GROM-SIL 100 ODS-2FE; GROM). Methanol:2-propanol (2:1, v/v) was used as the mobile phase and quinone was detected at $270 \mathrm{~nm}$. The peptidoglycan structure was elucidated by the Identification Service of the Deutsche Sammlung von Mikroorganismen und Zellkulturen (DSMZ; Braunschweig, Germany). The qualitative analyses of amino acids and peptides in peptidoglycan hydrolysates were carried out as described by Schleifer (1985) and Schleifer \& Kandler (1972) using paper chromatography (Rhuland et al., 1955). Quantitative analysis of amino acids in the total hydrolysate was performed by using GC and GC/MS as described by MacKenzie (1987) and Hasegawa et al. (1983). The $\mathrm{N}$ terminus of the interpeptide bridge was determined by dinitrophenylation according to Schleifer (1985). The DNA G $+\mathrm{C}$ content $(\mathrm{mol} \%)$ was determined by reversedphase HPLC using the method of Tamaoka \& Komagata (1984). The cellular fatty acid profile of the strain was characterized by the presence of saturated fatty acids such as anteiso- $\mathrm{C}_{15: 0}(40.0 \%)$, iso- $\mathrm{C}_{15: 0}(16.2 \%), \mathrm{C}_{16: 0}(12.7 \%)$ and iso- $\mathrm{C}_{16: 0}(8.1 \%)$ as the major fatty acids on TSA, and this pattern was similar to those of phylogenetically closely related species of the genus Paenibacillus. However, the proportions of anteiso- $\mathrm{C}_{15: 0}$ and iso- $\mathrm{C}_{15: 0}$ were lower and higher, respectively, than those reported for other Paenibacillus species (Table 2). Strain $\mathrm{YB}-45^{\mathrm{T}}$ contained meso-diaminopimelic acid as the diagnostic diamino acid in the cell-wall peptidoglycan, and the predominant isoprenoid quinone was MK-7. The DNA G $+\mathrm{C}$ content of strain YB$45^{\mathrm{T}}$ was $51.7 \mathrm{~mol} \%$. The major fatty acid profile, the isoprenoid quinone and the DNA G $+\mathrm{C}$ content are typical of the members of the group classically defined as constituting the genus Paenibacillus (Ash et al., 1993).

The 16S rRNA gene was amplified by a PCR using the Eubac 27F and 1492R primers (DeLong, 1992) and the PCR products were purified by using a QIAquick PCR purification kit (Qiagen). Sequencing of the purified 16S rRNA gene was performed by using an ABI PRISM BigDye Terminator cycle sequencing kit, as recommended by the manufacturer (Applied Biosystems), with five primers (337F, 785F, 1225F, $518 \mathrm{R}$ and $1100 \mathrm{R})$. The purified sequencing-reaction mixtures were electrophoresed automatically, using an Applied Biosystems model 377 automatic DNA sequencer. The 16S rRNA gene sequence of strain $\mathrm{YB}-45^{\mathrm{T}}$ was aligned with those of Paenibacillus species by using the CLUSTAL W program (Thompson et al., 1994). Sequence similarity values were computed by using SIMILARITY MATRIX version 1.1 (Ribosomal Database Project II; Cole et al., 2003). Gaps at the $5^{\prime}$ and $3^{\prime}$ ends of the alignment were omitted from further analysis. Phylogenetic trees were inferred by using three tree-making algorithms, i.e. the neighbour-joining (Saitou \& Nei, 1987), maximum-likelihood (Felsenstein, 1981) and maximum-parsimony (Kluge \& Farris, 1969)
Table 2. Cellular fatty acid compositions (\%) of the type strains of some Paenibacillus species and strain YB- $45^{\top}$

Strains: 1 , YB- $-45^{\mathrm{T}} ; 2, P$. polymyxa DSM $36^{\mathrm{T}} ; 3$, P. azotofixans DSM $5976^{\mathrm{T}}$; 4, P. peoriae DSM $8320^{\mathrm{T}}$; 5, P. kribbensis JCM $11465^{\mathrm{T}} ; 6, P$. terrae JCM $11466^{\mathrm{T}}$. -, Not detected.

\begin{tabular}{|c|c|c|c|c|c|c|}
\hline Fatty acid & 1 & 2 & 3 & 4 & 5 & 6 \\
\hline \multicolumn{7}{|l|}{ Saturated fatty acids } \\
\hline $\mathrm{C}_{11: 0} 2-\mathrm{OH}$ & - & 0.4 & - & - & - & - \\
\hline $\mathrm{C}_{14: 0}$ & 1.9 & 0.7 & 5.0 & 1.1 & 1.9 & 1.3 \\
\hline $\mathrm{C}_{15: 0}$ & 1.5 & 0.5 & 2.2 & 2.6 & 1.7 & 2.2 \\
\hline $\mathrm{C}_{16: 0}$ & 12.7 & 9.1 & 15.5 & 6.3 & 10.2 & 9.1 \\
\hline $\mathrm{C}_{16: 0} \mathrm{~N}$ alcohol & - & - & 0.4 & 0.1 & - & - \\
\hline $\mathrm{C}_{17: 0}$ & 0.3 & - & - & 0.4 & 0.5 & 0.3 \\
\hline $\mathrm{C}_{18: 0}$ & - & 1.1 & 0.3 & 0.1 & - & - \\
\hline \multicolumn{7}{|c|}{ Unsaturated fatty acids } \\
\hline $\mathrm{C}_{16: 1} \omega 11 c$ & 4.2 & - & - & - & 0.3 & 0.3 \\
\hline $\mathrm{C}_{17: 1} \omega 6 c$ & - & 0.7 & - & - & - & - \\
\hline $\mathrm{C}_{18: 1} \omega 5 c$ & - & - & 1.8 & - & - & - \\
\hline \multicolumn{7}{|l|}{ Branched fatty acids } \\
\hline iso- $\mathrm{C}_{13: 0}$ & 0.2 & - & 1.3 & 0.4 & - & 0.1 \\
\hline anteiso- $\mathrm{C}_{13: 0}$ & - & - & 1.8 & 0.3 & - & 0.2 \\
\hline iso- $\mathrm{C}_{14: 0}$ & 2.4 & 0.6 & 4.7 & 2.2 & 1.2 & 1.1 \\
\hline iso- $\mathrm{C}_{15: 0}$ & 16.2 & 5.5 & 8.7 & 8.7 & 10.4 & 6.5 \\
\hline anteiso- $\mathrm{C}_{15: 0}$ & 40.0 & 49.9 & 45.4 & 56.4 & 52.4 & 62.3 \\
\hline iso- $\mathrm{C}_{16: 0}$ & 8.1 & 7.7 & 5.3 & 7.4 & 6.4 & 4.5 \\
\hline iso- $\mathrm{C}_{17: 0}$ & 5.7 & 7.0 & 1.1 & 5.9 & 6.3 & 3.8 \\
\hline iso- $\mathrm{C}_{17: 0} 3-\mathrm{OH}$ & - & - & 2.9 & - & - & - \\
\hline anteiso- $\mathrm{C}_{17: 0}$ & 4.5 & 16.7 & 2.1 & 7.9 & 8.8 & 8.3 \\
\hline iso- $\mathrm{C}_{18: 1} \mathrm{H}^{\star}$ & - & - & 0.8 & - & - & - \\
\hline Summed feature $4 \dagger$ & 0.3 & - & 1.0 & - & - & - \\
\hline
\end{tabular}

${ }^{\star}$ The double bond position (indicated by a capital letter) is unknown. $\dagger$ Summed feature 4 represents iso- $\mathrm{C}_{17: 1} \mathrm{I}$ and/or anteiso- $\mathrm{C}_{17: 1} \mathrm{~B}$, which could not be separated by GLC using the MIDI system.

methods available in PHYLIP, version 3.65 (Felsenstein, 2005). Evolutionary distance matrices for the neighbour-joining method were calculated by using the algorithm of the Kimura two-parameter model (Kimura, 1980) with the DNADIST program. To evaluate the stability of the phylogenetic tree, a bootstrap analysis (1000 replications) was performed with the SEQBOOT, DNADIST, NEIGHBOR and CONSENSE programs in the PHYLIP package. The almostcomplete 16S rRNA gene sequence (1511 nt) of strain YB$45^{\mathrm{T}}$ was obtained; the $16 \mathrm{~S}$ rRNA gene sequence search performed using BLAST revealed that strain YB- $45^{\mathrm{T}}$ exhibited low levels of similarity (not more than $96 \%$ ) with respect to the recognized species of Paenibacillus, which is sufficient to indicate that strain $\mathrm{YB}-45^{\mathrm{T}}$ represents a novel species of a genus (Stackebrandt \& Goebel, 1994). The levels of $16 \mathrm{~S}$ rRNA gene sequence similarity between strain YB- $45^{\mathrm{T}}$ and Paenibacillus jamilae DSM $13815^{\mathrm{T}}$, Paenibacillus terrae JCM $11466^{\mathrm{T}}$, Paenibacillus polymyxa DSM $36^{\mathrm{T}}$, Paenibacillus azotofixans DSM 5976 ${ }^{\mathrm{T}}$, Paenibacillus peoriae DSM $8320^{\mathrm{T}}$, Paenibacillus brasilensis DSM $14914^{\mathrm{T}}$ and Paenibacillus kribbensis JCM $11465^{\mathrm{T}}$ were 95.7, 95.5, 95.5, 95.4, 95.3, 
95.2 and $95.2 \%$, respectively. The phylogenetic tree (Fig. 1) constructed by using neighbour-joining analysis showed that strain YB- $45^{\mathrm{T}}$ was affiliated to the genus Paenibacillus and formed a distinct phylogenetic line $(68.4 \%$ bootstrap support) with respect to closely related species. The topologies of the phylogenetic trees constructed by using the maximum-likelihood and maximum-parsimony algorithms were similar to that of the tree constructed with neighbour joining (data not shown).

Therefore, on the basis of the data presented, we propose that strain $\mathrm{YB}-45^{\mathrm{T}}$ represents a novel species of the genus Paenibacillus, for which the name Paenibacillus woosongensis sp. nov. is proposed.

\section{Description of Paenibacillus woosongensis sp. nov.}

Paenibacillus woosongensis (woo.song.en'sis. N.L. masc. adj. woosongensis of Woosong, the Korean name for the university in Korea at which the organism was isolated).

Cells are xylanolytic, Gram-variable, motile, aerobic or facultatively anaerobic, endospore-forming (ellipsoidal, terminal) rods measuring $0.5-0.7 \times 2.5-5.0 \mu \mathrm{m}$. Colonies on TSA medium are circular with slightly irregular edges, low convex, light beige to greyish, translucent, glossy and usually
1-2 $\mathrm{mm}$ in diameter within $48 \mathrm{~h}$ at $37^{\circ} \mathrm{C}$. Growth occurs at $28-47^{\circ} \mathrm{C}$ (optimum, $37{ }^{\circ} \mathrm{C}$ ) and from $\mathrm{pH} 6.0$ to 10.6 (optimum, $\mathrm{pH} 7.5)$. Grows at salinities of $0-3 \%(\mathrm{w} / \mathrm{v})$ $\mathrm{NaCl}$ (optimum, $3 \% \mathrm{NaCl}$ ). No growth occurs in the presence of $>5 \% \mathrm{NaCl}$. Oxidase-negative and catalasepositive. Nitrate is not reduced to nitrite. Aesculin, casein and starch are hydrolysed; tyrosine, Tween 80 , gelatin and urea are not hydrolysed. L-Arabinose, CM-cellulose, Dfructose, galactose, gluconate, glucose, D-ribose, starch, xylan and D-xylose are utilized; 5-keto-D-gluconate, D-arabinose, rhamnose and xylitol are utilized weakly as sole carbon and energy sources. 2-Keto-D-gluconate, citrate, glycerol, sorbitol, sorbose and succinate are not utilized as sole carbon and energy sources. Acid is produced from amygdalin, arabinose, arbutin, D-cellobiose, D-fructose, D-galactose, gentiobiose, gluconate, D-glucose, glycogen, inulin, D-lactose, D-lyxose, maltose, D-mannose, melibiose, methyl $\beta$-D-xylopyranoside, $\mathrm{N}$-acetylglucosamine, raffinose, D-ribose, salicin, sucrose, trehalose, turanose and D-xylose; acid is produced weakly from xylitol. Acid is not produced from 2-keto-D-gluconate, 5-keto-D-gluconate, D-adonitol, arabitol, dulcitol, erythritol, fucose, gluconate, glycerol, inositol, melezitose, methyl $\alpha$-Dglucopyranoside, methyl $\alpha$-D-mannopyranoside, D-sorbitol, L-sorbose, D-tagatose or L-xylose. Xylanase, cellulase, amylase, $\beta$-mannanase, $\beta$-mannosidase, $\beta$-xylosidase, $\alpha$-galactosidase, $\beta$-galactosidase and $\beta$-glucosidase are produced. The

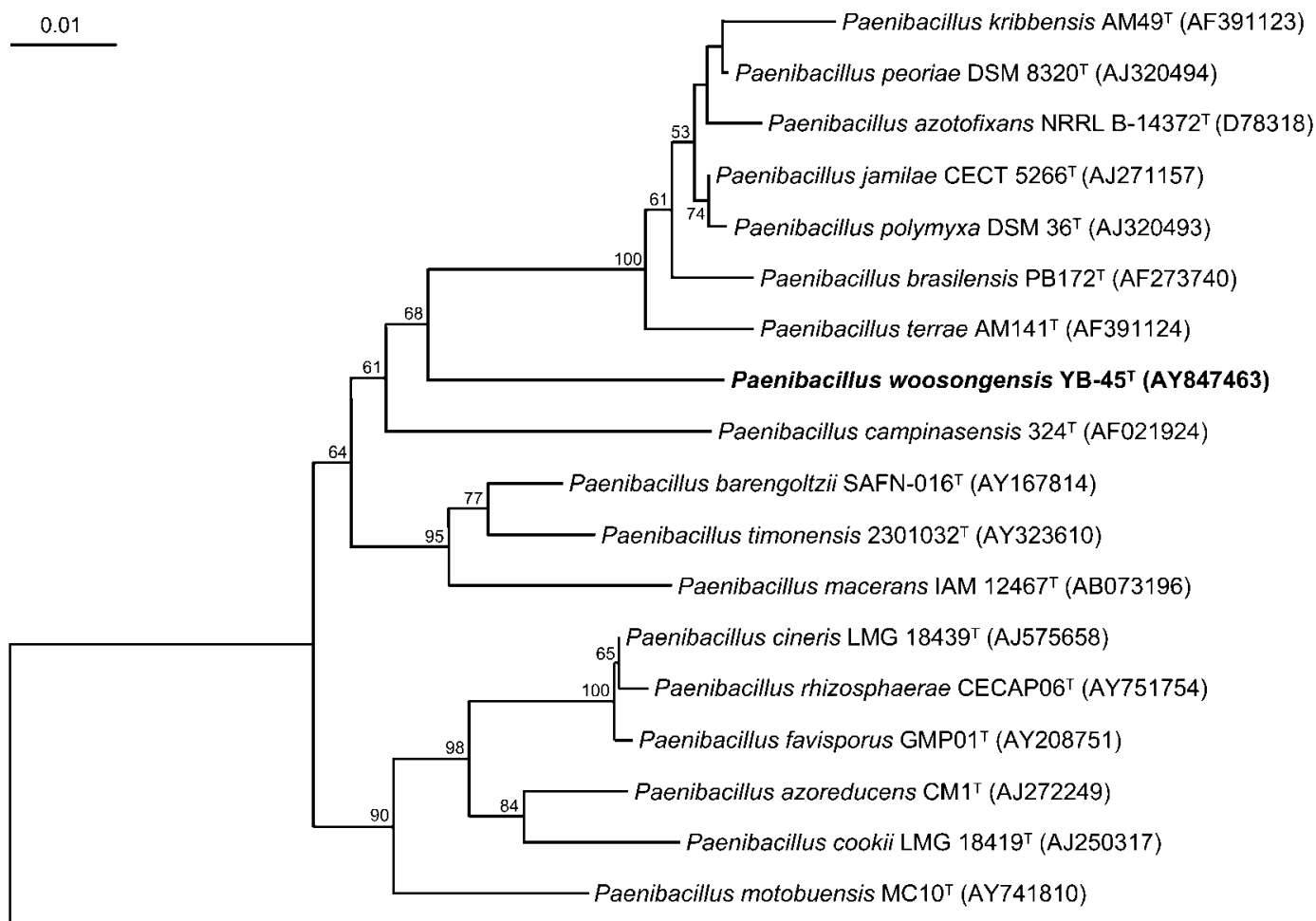

Bacillus subtilis NCIMB $3610^{\top}(X 60646)$

Fig. 1. Neighbour-joining tree based on $16 \mathrm{~S}$ rRNA gene sequences, showing the phylogenetic relationships of strain $\mathrm{YB}^{-45^{\top}}$

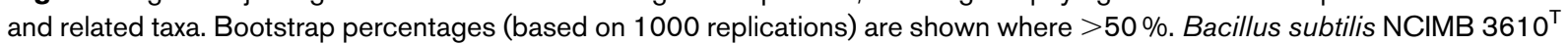
was used as an outgroup. Bar, 0.01 substitutions per nucleotide position. 
cell-wall peptidoglycan contains meso-diaminopimelic acid. The predominant menaquinone is MK-7. The major fatty acid is anteiso- $\mathrm{C}_{15: 0}$. The DNA $\mathrm{G}+\mathrm{C}$ content of the type strain is $51.7 \mathrm{~mol} \%$.

The type strain, YB- $45^{\mathrm{T}}\left(=\right.$ KCTC $3953^{\mathrm{T}}=$ DSM $\left.16971^{\mathrm{T}}\right)$, was isolated from forest soil at Daejeon in Korea.

\section{References}

Ash, C., Priest, F. G. \& Collins, M. D. (1993). Molecular identification of rRNA group 3 bacilli (Ash, Farrow, Wallbanks and Collins) using a PCR probe test. Proposal for the creation of a new genus Paenibacillus. Antonie van Leeuwenhoek 64, 253-260.

Ash, C., Priest, F. G. \& Collins, M. D. (1994). Paenibacillus gen. nov. In Validation of the Publication of New Names and New Combinations Previously Effectively Published Outside the IJSB, List no. 51. Int J Syst Bacteriol 44, 852.

Aÿ, J., Goetz, F., Borriss, R. \& Heinemann, U. (1998). Structure and function of the Bacillus hybrid enzyme GluXyn-1: native-like jellyroll fold preserved after insertion of autonomous globular domain. Proc Natl Acad Sci U S A 95, 6613-6618.

Cole, J. R., Chai, B., Marsh, T. L., Farris, R. J., Wang, Q., Kulam, S. A., Chandra, S., McGarrell, D. M., Schmidt, T. M. \& other authors (2003). The ribosomal database project (RDP-II): previewing a new autoaligner that allows regular updates and the new prokaryotic taxonomy. Nucleic Acids Res 31, 442-443.

Cowan, S. T. \& Steel, K. J. (1965). Manual for the Identification of Medical Bacteria. London: Cambridge University Press.

DeLong, E. F. (1992). Archaea in coastal marine environments. Proc Natl Acad Sci U S A 89, 5685-5689.

Felsenstein, J. (1981). Evolutionary trees from DNA sequences: a maximum likelihood approach. J Mol Evol 17, 368-376.

Felsenstein, J. (2005). PHYLIP (phylogeny inference package), version 3.65. Distributed by the author. Department of Genome Sciences, University of Washington, Seattle, USA.

Hasegawa, T., Takizawa, M. \& Tanida, S. (1983). A rapid analysis for chemical grouping of aerobic actinomycetes. J Gen Appl Microbiol 29, 319-322.

Hespell, R. B. (1996). Fermentation of xylan, corn fiber, or sugars to acetoin and butanediol by Bacillus polymyxa strains. Curr Microbiol 32, 291-296.

Kimura, M. (1980). A simple method for estimating evolutionary rates of base substitutions through comparative studies of nucleotide sequences. J Mol Evol 16, 111-120.

Kluge, A. G. \& Farris, F. S. (1969). Quantitative phyletics and the evolution of anurans. Syst Zool 18, 1-32.

Komagata, K. \& Suzuki, K. (1987). Lipid and cell-wall analysis in bacterial systematics. Methods Microbiol 19, 161-207.

Lamed, R., Bayer, E., Saha, B. C. \& Zeikus, J. G. (1988). Biotechnological potential of enzyme from unique thermophiles. In Proceedings of the Eighth International Biotechnology Symposium, pp. 371-383. Edited by G. Durand, L. Bobichon \& J. Florent. Paris: French Society for Microbiology.

Lanyi, B. (1987). Classical and rapid identification methods for medically important bacteria. Methods Microbiol 19, 1-67.

Lee, H. J., Shin, D. J., Cho, N. C., Kim, H. O., Shin, S. Y., Im, S. Y., Lee, H. B., Chum, S. B. \& Bai, S. (2000). Cloning, expression and nucleotide sequences of two xylanase genes from Paenibacillus sp. Biotechnol Lett 22, 387-392.
MacKenzie, S. L. (1987). Gas chromatographic analysis of amino acids as the N-heptafluorobutyryl isobutyl esters. J Assoc Off Anal Chem 70, 151-160.

Morales, P., Madarro, A., Flors, A., Sendra, J. M. \& Pérez-González, J. A. (1995). Purification and characterization of a xylanase and an arabinofuranosidase from Bacillus polymyxa. Enzyme Microb Technol 17, 424-429.

Nielsen, P. \& Sorensen, J. (1997). Multi-target and mediumindependent fungal antagonisms by hydrolytic enzymes in Paenibacillus polymyxa and Bacillus pumilus strains from barley rhizosphere. FEMS Microbiol Ecol 22, 183-192.

Rhuland, L. E., Work, E., Denman, R. F. \& Hoare, D. S. (1955). The behaviour of the isomers of $\alpha, \varepsilon$-diaminopimelic acid on paper chromatograms. J Am Chem Soc 77, 4844-4846.

Rivas, R., Mateos, P., Martines-Molina, E. \& Velázquez, E. (2005). Paenibacillus xylanilyticus sp. nov., an airborne xylanolytic bacterium. Int J Syst Evol Microbiol 55, 405-408.

Saitou, N. \& Nei, M. (1987). The neighbor-joining method: a new method for reconstructing phylogenetic trees. Mol Biol Evol 4, 406-425.

Schleifer, K. H. (1985). Analysis of the chemical composition and primary structure of murein. Methods Microbiol 18, 123-156.

Schleifer, K. H. \& Kandler, O. (1972). Peptidoglycan types of bacterial cell walls and their taxonomic implications. Bacteriol Rev 36, 407-477.

Smibert, R. M. \& Krieg, N. R. (1981). General characterization. In Manual of Methods for General Bacteriology, pp. 409-443. Edited by P. Gerhardt, R. G. E. Murray, R. N. Costilow, E. W. Nester, W. A. Wood, N. R. Krieg \& G. B. Phillips. Washington, DC: American Society for Microbiology.

Smibert, R. M. \& Krieg, N. R. (1994). Phenotypic characterization. In Methods for General and Molecular Bacteriology, pp. 607-654. Edited by P. Gerhardt, R. G. E. Murray, W. A. Wood \& N. R. Krieg. Washington, DC: American Society for Microbiology.

Stackebrandt, E. \& Goebel, B. M. (1994). Taxonomic note: a place for DNA-DNA reassociation and $16 \mathrm{~S}$ rRNA sequence analysis in the present species definition in bacteriology. Int J Syst Bacteriol 44, 846-849.

Tamaoka, J. \& Komagata, K. (1984). Determination of DNA base composition by reversed-phase high-performance liquid chromatography. FEMS Microbiol Lett 25, 125-128.

Thompson, J. D., Higgins, D. G. \& Gibson, T. J. (1994). CLUSTAL W: improving the sensitivity of progressive multiple sequence alignment through sequence weighting, position-specific gap penalties and weight matrix choice. Nucleic Acids Res 22, 4673-4680.

Timell, T. E. (1967). Recent progress in the chemistry of wood hemicelluloses. Wood Sci Technol 1, 45-70.

Velázquez, E., de Miguel, T., Poza, M., Rivas, R., Rosselló-Mora, R. \& Villa, T. G. (2004). Paenibacillus favisporus sp. nov., a xylanolytic bacterium isolated from cow faeces. Int J Syst Evol Microbiol 54, 59-64.

Viikari, L., Kantelinen, A., Sundquist, J. \& Linko, M. (1994). Xylanases in bleaching: from an idea to the industry. FEMS Microbiol Rev 13, 335-350.

von der Weid, I., Frois Duarte, G., van Elsas, J. D. \& Seldin, L. (2002). Paenibacillus brasilensis sp. nov., a novel nitrogen-fixing species isolated from the maize rhizosphere in Brazil. Int J Syst Evol Microbiol 52, 2147-2153.

Yoon, J.-H., Oh, H.-M., Yoon, B.-D., Kang, K. H. \& Park, Y.-H. (2003). Paenibacillus kribbensis sp. nov. and Paenibacillus terrae sp. nov., bioflocculants for efficient harvesting of algal cells. Int J Syst Evol Microbiol 53, 295-301.

Zamost, B. L., Nielsen, H. K. \& Starnes, R. L. (1991). Thermostable enzymes for industrial applications. J Ind Microbiol 8, 71-82. 